\title{
CURBING ACTINOMYCETES AND THIDIAZURON ENHANCED MICROPROPAGATION IN THE RARE ALPINIA GALANGA - A MEDICINAL ZINGIBER
}

\author{
BARADWAJ RG, RAO MV*, SENTHIL KUMAR T \\ Department of Plant Science, Bharathidasan University, Tiruchirappalli, Tamil Nadu, India. Email mvrao_456@yahoo.co.in
}

Received: 14 February 2017, Revised and Accepted: 13 April 2017

ABSTRACT

Objective: Elimination of endophytic actinomycetes before micropropagation using antibiotic pre-treatment in rhizome bud explants of Alpinia galanga. Formulation of an operative protocol for micropropagation from the disinfected rhizome bud explants in Alpinia galanga.

Methods: A treatment of mercury chloride and carbendazim, alone and in combination was used as surface sterilants. A pre-treatment of rifampicin and fusidic acid was used against actinomycete endophyte disinfection of rhizome bud explants. Then, Murashige and Skoog (MS) medium supplemented with various concentrations of cytokinins was used for micropropagation of disinfected explants.

Results: A treatment of $0.1 \%(\mathrm{w} / \mathrm{v})$ mercury chloride and $0.1 \%(\mathrm{w} / \mathrm{v})$ carbendazim, one after the other for 5 minutes gave the best sterility of $83.3 \%$. A pre-treatment of Rifampicin $100 \mathrm{mg} / \mathrm{l}$ and fusidic acid $100 \mathrm{mg} / \mathrm{l}$ for $2 \mathrm{hrs}$ gave the best disinfection of $70 \%$ against actinomycete endophytes. A combination of thidiazuron (TDZ) $0.45 \mu \mathrm{M}$ and 6-benzyladenine $13.32 \mu \mathrm{M}$ in MS medium resulted in 9.4 shoots per explant. MS medium fortified with $10.74 \mu$ Mof 1-naphthaleneacetic acid gave the best rooting of 20 roots/shoot. Inter simple sequence repeat marker genetic similarity of regenerants with the mother plant was confirmed.

Conclusion: This study shows the potency of Rifampicin and Fusidic acid to disinfect explants from actinomycete endophytes and is significant as the first report on curbing actinomycetes endophytes in plant tissue culture of A. galanga. This is also the first report conferring the dissimilar regeneration capabilities of TDZ in comparison to other cytokinins in Zingiberaceae.

Keywords: Alpinia galanga, Rifampicin, Fusidic acid, Actinomycetes, Thidiazuron, Inter simple sequence repeat.

(C) 2017 The Authors. Published by Innovare Academic Sciences Pvt Ltd. This is an open access article under the CC BY license (http://creativecommons. org/licenses/by/4. 0/) DOI: http://dx.doi.org/10.22159/ajpcr.2017.v10i7.17734

\section{INTRODUCTION}

Effective in vitro plant regeneration is greatly essential for application of most modern biotechnological practices in crop enhancement [1]. Alpinia galanga has been propagated via tissue culture using micropropagation, direct and indirect organogenesis with rhizome buds as explants [2-5], but the success of these efforts varies significantly, possibly due to the presence of endophytic actinomycetes in the rhizomes of A. galanga [6-8]. This interference in regeneration capability could be caused by the plant growth promoting the activity of indole-3pyruvic acid and indole-3-acetic acid (IAA) produced by the endophytic Actinomycetes $[9,10]$. The presence of endophytic actinomycetes greatly affects commercial tissue culture both qualitatively and quantitatively; moreover, tissue cultured plants harboring these endophytes are not suitable for export due to plant quarantine.

A. galanga (L.) Willd. (Zingiberaceae) occurring in the Western Ghats of south India, northeastern parts of India and Thailand is the type species of the genus Alpinia Roxb. It is an important cultivated medicinal crop in India and is recognized in different traditional systems of medicine to treat microbial infections, inflammations, rheumatic pains, chest pain, dyspepsia, fever, diabetes, burning of the liver, kidney disease, tumors, and even HIV [11]. Galangin, a flavone present in A. galanga, has exhibited potent cardioprotective activity against doxorubicin-induced cardiomyopathy in Wistar rats [12]. The plant comprises many such pharmacologically important phytochemicals, namely, 1'S'-1'-acetoychavicol acetate, 1'S'-1'-acetoyeugenol acetate, 1'S'-1'-hydroxychavicol acetate, trans-p-coumaryl alcohol, trans-p-hydroxycinnamyl acetate, trans-p- coumaryl diacetate and nortrachelogenin, caryophyllene, cubenol and eucalyptol [13-18].
The validating genetic integrity of in vitro regenerated plants with regard to the mother plant is indispensable for the maintenance of certain horticultural and agronomic traits [19]. There are odds of getting somaclonal variations among the regenerants in plant tissue culture due to the impact of factors such as donor genotype, explant type, culture medium composition, physical culture conditions, the duration between successive subcultures and particular reagents used for various techniques which are possibly heritable [20]. Thus, there ascends the need to appraise whether the regenerants are genetically identical to the mother plant.

Due to the increased therapeutic and pharmaceutical demand, the status of $A$. galanga in the wild has been significantly affected, and it has gained a threatened to endangered status in the Western Ghats of India [21]. Therefore, to fulfill the demand of pharmaceutical industries and as a preliminary prerequisite for reintroduction or cultivation of the medicinal crop, the establishment of an efficient in vitro regeneration system void of glitches is required. The past reports of in vitro plant regeneration in this important medicinal crop are at best ineffective and unreproducible due to the non-elimination of endophytic actinomycetes pedant in the rhizome of the plant as mentioned above. The short-term use of antibiotics such as rifampicin has long been used in plant tissue culture for disinfecting plants without affecting their growth [22]. As there are no methods for successful disinfection of actinomycete in plant tissue culture yet and since the maintenance of genetic characters of the high-class mother plant in in vitro raised plants is imperative, the present study was devised to use antibiotic pre-treatments as an effective technique to avail actinomycete free explants of A. galanga for micropropagation and to assert the inter-simple sequence repeat (ISSR) genetic fidelity of in vitro produced plantlets. 


\section{METHODS}

Plant material, surface sterilization, and antibiotic pre-treatment Mature rhizomes of A. galanga were collected from Kerala Forest Research Institute, Peechi, Kerala, India, and plants were retained in the department of Plant science, Bharathidasan University, Tiruchirappalli, Tamil Nadu, India, and used as explant source. The plant was identified through standard herbarium specimen submitted to the Botanical Survey of India, Southern Circle, Coimbatore, Tamil Nadu, India, and was identified as A. galanga var. Galanga (accession number-177088).

Rhizome bud explants $(0.5-1 \mathrm{~cm})$ were rinsed with a few drops of teepol and then subjected to running tap water for 30 minutes to remove surface debris. Further, the explants were surface sterilized with mercury chloride $0.1 \%(\mathrm{w} / \mathrm{v})$, carbendazim $0.1 \%(\mathrm{w} / \mathrm{v})$, and both, one after the other in sequence for 2, 5, and 7 minutes. There were 10 explants per treatment, and the experiment was conducted in triplicate. The explants were washed twice with sterile distilled water after each sterilization treatment for 2 minutes.

The surface sterilized explants were pre-treated with antibiotics such as Rifampicin ([Rif] 25, 50, 100, and $200 \mathrm{mg} / \mathrm{l}$ ), fusidic acid ([Fus] 50 and $100 \mathrm{mg} / \mathrm{l}$ ), and their combinations. The treatments were carried out for time periods $1 / 2 \mathrm{hr}, 1 \mathrm{hr}$, and $2 \mathrm{hrs}$. Finally, the explants were washed twice with sterile distilled water for 15 minutes after the treatment.

\section{Culture conditions and contamination screening}

The explants were inoculated aseptically using a laminar air flow chamber on separate glass test tubes $(25 \mathrm{~cm} \times 1.5 \mathrm{~cm})$ containing Murashige and Skoog (MS) medium [23] gelled with $0.7 \%(\mathrm{w} / \mathrm{v})$ agar and $3 \%(\mathrm{w} / \mathrm{v})$ sucrose as carbon source (Basal MS). The $\mathrm{pH}$ of the medium was adjusted to 5.8 before it was autoclaved $\left(121^{\circ} \mathrm{C}\right.$ and $100 \mathrm{kPa}$ for 15 minutes). The medium was supplemented with plant growth regulators of different concentrations before adjusting its $\mathrm{pH}$, according to the experiments. The cultures were maintained in a $16 \mathrm{hrs}$ photoperiod $\left(25 \mu \mathrm{Mol} / \mathrm{m} \mathrm{s}^{-1}, 400-700 \mathrm{~nm}\right.$, cool white fluorescent light) (Phillips, India) with a culture room temperature of $25 \pm 2^{\circ} \mathrm{C}$

The surface sterilized explants were screened on basal MS medium for 1 week for inferring any contamination. The data on sterility and necrosis of the explants were documented, and percentage sterility and necrosis were calculated for the various treatments and time periods. Then, the explants were subjected to antibiotic pre-treatment and were screened on MS medium with $6 \%(\mathrm{w} / \mathrm{v})$ sucrose and $0.1 \%(\mathrm{w} / \mathrm{v})$ casein hydrolysate. The data on sterility of explants were noted after 2 weeks, and the percentage sterility was calculated.

\section{Multiple shoots induction}

Two experiments were done one based on the other, wherein the first experiment the outcome of individual cytokinins 6-benzyladenine (BA), kinetin (KN), thidiazuron (TDZ), zeatin and N6-[2-isopentenyl]adenine (2ip) were studied on induction of multiple shoots. The explants were inoculated on MS medium fortified with the above cytokinins, except for TDZ all the other cytokinins were screened at higher concentrations in the range between 4.44 and $14.76 \mu \mathrm{M}$ and TDZ was screened at concentrations between 0.22 and $2.25 \mu \mathrm{M}$. In the second experiment, MS medium sublimated with TDZ $0.45 \mu \mathrm{M}$ in combination with BA 04.44, 08.87, and $13.32 \mu \mathrm{M}$ was studied. Data were analyzed after 8 weeks of culture, and the number of shoots, roots, and leaves per shoot for each explant was documented.

\section{Rooting and hardening}

Rooting was studied separately on MS medium fortified with auxins IAA, indole-3-butyric acid (IBA) and 1-naphthaleneacetic acid (NAA) at concentrations ranging from 4.90 to $17.13 \mu \mathrm{M}$ as auxins produced much better rooting than cytokinins, NAA in particular. The data were analyzed after 8 weeks of culture. Hardening was done on autoclaved sand, soil, and coco peat $(1: 1: 1[\mathrm{w} / \mathrm{w} / \mathrm{w}])$ after separating individual shoots with copious roots. The hardening process was done inside a closed plastic container to simulate high humidity for 2 months and then grown plants were further hardened on the same mixture covered with transparent polythene bags $(12 \times 8 \mathrm{~cm}$, Tarson, New Delhi, India $)$ for four further months; then, they were potted on normal garden soil. The chemicals used in the above experiments were purchased from HiMedia Pvt. Ltd. (Mumbai, India).

\section{Genetic fidelity testing}

Fidelity of in vitro raised clones was tested using ISSR markers. Total genomic DNA was extracted from the leaves of the mother plant and randomly selected micropropagated plantlets using the modified CTAB method [24]. Quality and concentration of DNA were assessed visually by band intensity in contrast with Lambda DNA of fixed concentration using a $0.8 \%$ agarose gel. The DNA samples were maintained in trisethylenediaminetetraacetic acid buffer and stored at $4^{\circ} \mathrm{C}$ for further analysis. ISSR analysis was initiated with 10 primers, namely, University of British Columbia (UBC-807), UBC-808, UBC-809, UBC-835, UBC-842, UBC-855, UBC-856, UBC-857, UBC-866, and (ACTG) ${ }_{4}$. The polymerase chain reaction polymerase chain reaction (PCR) was carried out in $25 \mu$ reactions $\left(12.5 \mu \mathrm{l} 2 \mathrm{X}\right.$ TaKaRa Taq $^{\text {TM }}$ Premix, $2.5 \mu$ primer $(0.5 \mu \mathrm{M})$, $2 \mu \mathrm{l}$ of template DNA and $8 \mu \mathrm{l}$ of double distilled water). The PCR were run in a DNA thermal cycler (MJ Mini ${ }^{\mathrm{TM}} 48$-well personal thermal cycler, Bio-Rad, USA) with one primer in each reaction. The PCR amplification profile for all the primers was $98^{\circ} \mathrm{C}$ for 120 seconds, 35 cycles of $98^{\circ} \mathrm{C}$ for 30 seconds, $50^{\circ} \mathrm{C}$ for 90 seconds, $72^{\circ} \mathrm{C}$ for 60 seconds, final extension $72^{\circ} \mathrm{C}$ for 300 seconds, and $4^{\circ} \mathrm{C}$ for infinity. The PCR products were run with $4 \mu \mathrm{l}$ of $6 \mathrm{X}$ DNA loading buffer on $1,1.2$, and $1.5 \%$ agarose gels for ISSR which was prepared in 1 X TBE buffer containing $0.5 \mu \mathrm{g} / \mathrm{ml}$ of Ethidium bromide. A GeneRuler ${ }^{\mathrm{TM}}$, Thermo Scientific, Massachusetts, USA, $1 \mathrm{~kb}$ Plus DNA Ladder was used. The amplified products were electrophoresed and after separation gels were documented using a ChemiDoc $^{\text {TM }}$ XRS+ imaging system, Bio-Rad, USA.

Only clear and reproducible bands were scored, but a prominent band conforming to a feeble band in other repeats was also considered in the analysis. Each and every band was considered as a marker. Bands with identical mobility and molecular weight were reflected as a single locus.

\section{Statistical analysis}

All experiments were setup in a completely random design and conducted in quintuplicate with the same culture conditions unless otherwise specified. The mean values of results obtained from various plant growth regulators were subjected to a one-way ANOVA, and Duncan's Multiple Range test was used for comparing means (SPSS 16.0 software, SPSS Inc., Chicago, IL, USA) in the multiple shoots induction and rooting experiments. The statistical significance was set to $\mathrm{p}=0.05$.

\section{RESULTS}

\section{Surface sterilization}

In the present study, it was found that surface sterilization with $0.1 \%$ $(\mathrm{w} / \mathrm{v})$ mercury chloride alone and in combination with $0.1 \%(\mathrm{w} / \mathrm{v})$ carbendazim, one after the other for 7 minutes gave $96.7 \%$ and $100 \%$ sterility, but it was observed that the necrosis of explants was too high, which was $76.7 \%$ and $96.7 \%$, respectively. Therefore, based on the surface sterilization experiment, it was concluded that a treatment of $0.1 \%(\mathrm{w} / \mathrm{v})$ mercury chloride and $0.1 \%(\mathrm{w} / \mathrm{v})$ carbendazim, one after the other for 5 minutes, which gave a sterility of $83.3 \%$ and had a necrosis of $16.7 \%$ was considered as the best sterilization treatment for the rhizome bud explants (Fig. 1).

\section{Antibiotic pre-treatment and contamination screening}

In the present study, instead of adding antibiotics to the medium, a pre-treatment of antibiotics for a shorter stipulated time was followed. Rifampicin $200 \mathrm{mg} / \mathrm{l}$ for $2 \mathrm{hrs}$ gave a disinfection of $70 \%$ against actinomycetes but is a very high concentration of the antibiotic, thus rifampicin $100 \mathrm{mg} / \mathrm{l}$ and fusidic acid $100 \mathrm{mg} / \mathrm{l}$ for 2 hrs which also gave $70 \%$ disinfection against actinomycetes was considered (Fig. 2), since a combination can screen a wider range. The treated explants were inoculated on MS medium fortified with $6 \%$ sucrose and $0.1 \%$ casein hydrolysate since they are common constituents of actinomycete 


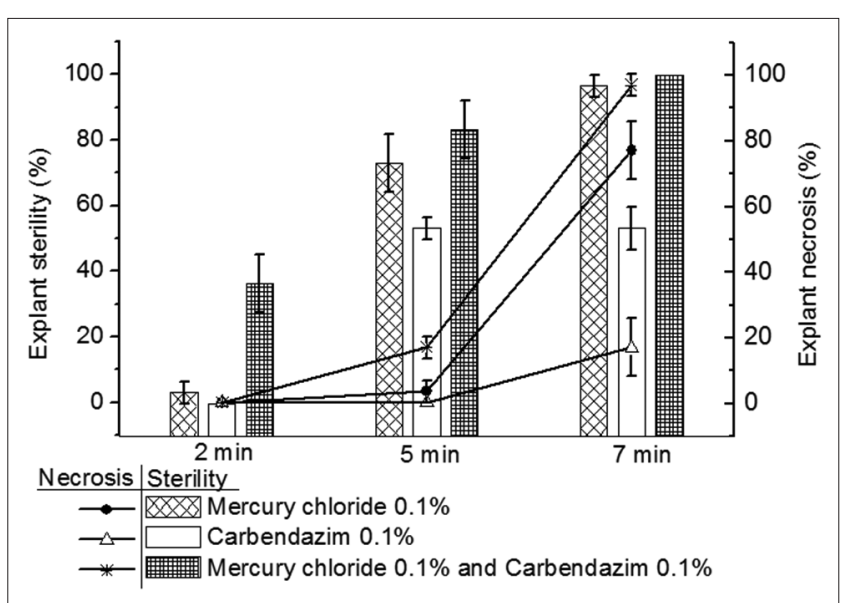

Fig. 1 Percentage sterility versus necrosis of Alpinia galanga explants after surface sterilization

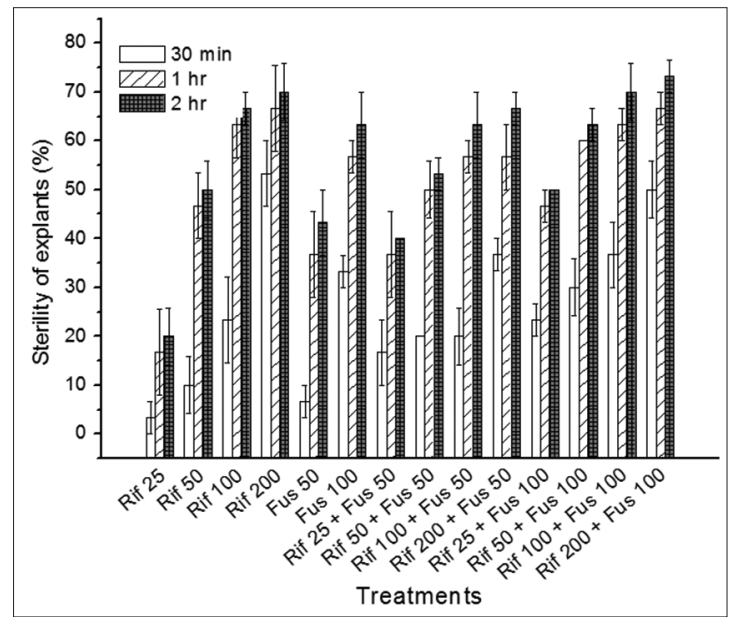

Fig. 2 Percentage sterility of Alpinia galanga explants after surface sterilization and antibiotic treatment

medium preparations, which promoted exiting of endogenous actinomycetes on to the medium (Fig. 3a).

\section{Cytokinins on multiple shoots induction}

The maximum number of shoots after 8 weeks' time was observed on MS medium fortified with BA $13.32 \mu \mathrm{M}$ (4.6), followed by TDZ $0.45 \mu \mathrm{M}$ (4.2) (Fig. 3d and e). Multiple shoot induction in the presence of BA and TDZ was significantly higher compared to control (basal MS) after 8 weeks of culture (Table 1). The minimum multiple shoots in a cytokinin were observed in 2ip which was as low as the control (data not shown). All the cytokinins simultaneously produced roots, with a maximum of 6.4 in $\mathrm{KN} 13.94 \mu \mathrm{M}$ and a minimum of 1.6 in TDZ $0.22 \mu \mathrm{M}$. Maximum number of leaves (4/shoot) was observed in 2ip $14.76 \mu \mathrm{M}$ (data not shown) and the minimum was in TDZ $0.22 \mu \mathrm{M}$ (Table 1 ).

\section{Interaction between BA and TDZ on multiple shoots induction}

The MS medium supplemented with $0.45 \mu \mathrm{M}$ TDZ in synergy with 13.32 $\mu$ M BA showed the best multiple shoot producing (9.4) (Fig. 3f). Number of leaves produced were not much affected but rooting significantly increased when TDZ was combined with BA forming a maximum of 6.4 roots per shoot in contrast to 2.2 roots which was maximum in TDZ $0.22 \mu \mathrm{M}$.

\section{Rooting and hardening}

In the present study, IAA and IBA also produced roots consistent with other studies on Zingiberaceae members $[25,26]$ but when shoots were cultivated on MS medium with NAA they produced significantly greater number of roots among which the maximum was on $10.74 \mu \mathrm{M}$ NAA (20) (Table 2) (Fig. 3g and i). Initial hardening was done in plastic cups filled with soil, sand, and coco peat (1:1:1), the potted plants were kept in plastic containers for maintaining high moisture content (Fig. $3 \mathrm{j}$ and $\mathrm{k}$ ). This hardening process was extended for 4 months after which the rhizomes were thick and prominent enough for transfer to the field (Fig. $3 \mathrm{l}$ and $\mathrm{m}$ ). The survival rate of the hardened plants was $80 \%$.

\section{Genetic fidelity testing}

Among the 10 ISSR primers employed in the initial screening, 7 produced clear and reproducible bands. The annealing temperature for all the ISSR markers used was $55^{\circ} \mathrm{C}$. The 7 ISSR primers formed 51 distinct and scorable bands ranging from $200 \mathrm{bp}$ to $2000 \mathrm{bp}$ in size. The scorable bands for the various primers varied from 3 (UBC-856) to 14 (UBC-842) (Fig. 4) with a mean of 7 bands per primer. The banding profiles from the various micropropagated plants exhibited complete monomorphicity and exhibited $100 \%$ similarity to those of the mother plant.

\section{DISCUSSION}

\section{Surface sterilization}

Since the rhizome bud explants are of underground origin rinsing them thoroughly with running tap water was a must to remove surface debris and to reduce the inoculum of surface microbes [25]. Mercury chloride was subjected as a general purpose sterilant as it works against a broad range of microbes especially bacteria, it attacks the protein sulfhydryl groups and disrupts normal enzyme functioning [27]. Carbendazim also called as Bavistin is a broad range systemic fungicide which works against fungi by causing microtubule disrupting [28]. Mercury chloride and carbendazim were used in concentrations $0.1 \%(\mathrm{w} / \mathrm{v})$ and more for above 5 minutes to avail good sterile explants in the genus Alpinia and species A. galanga for the rhizome bud explants [2-5], but in contrary, it was found in the current study that mercury chloride and carbendazim caused greater percentage of necrosis in explants when the treatment exceeded 5 minutes (Fig. 2).

\section{Antibiotic pre-treatment and contamination screening}

Antibiotics have long been used in plant tissue culture as media supplements but since some of them are known inhibitors of nucleic acid metabolism, protein synthesis or even plant growth they are not mainstream. Rifampicin is a competitive inhibitor of RNA polymerase and is well known for its wide range activity against actinomycetes [29]. Fusidic acid hinders protein synthesis by inhibition of an elongation factor at the level of the ribosome and is found to be very effective against actinomycetes in synergy with rifampicin [30]. This is the first report of using rifampicin and fusidic acid pre-treatments for actinomycete elimination in plant tissue culture.

\section{Cytokinins on multiple shoots induction}

The motive of a micropropagation protocol is basically to produce a large number of genotypically uniform plantlets analogous to the original plant; this is evident using meristematic regions. In the present study, the rhizome bud explant which has a prominent meristematic region was used, and regeneration from such meristematic regions is considered as micropropagation (Fig. 3b and c). Shoot initiation began in 2 weeks' period in all treatments except for TDZ in which the shoots started forming in around 3 weeks' time.

Micropropagation studies in Alpinia zerumbet and Alpinia purpurata have already shown that BA is very effective in producing shoots from rhizome bud explants [26,31], which concurs with the current study. Aframomum corrorima also a Zingiberaceae member has shown good micropropagation of rhizome buds by supplementing BA and TDZ in MS medium as in the present study, but they have not discussed their synergistic effect [32].

Interaction between $\mathrm{BA}$ and TDZ on multiple shoots induction Comparing Fig. $3 \mathrm{~d}$ and e and $\mathrm{f}$ an interaction is clear between BA and TDZ on multiple shoot initiation in A. galanga after 8 weeks of culture. 

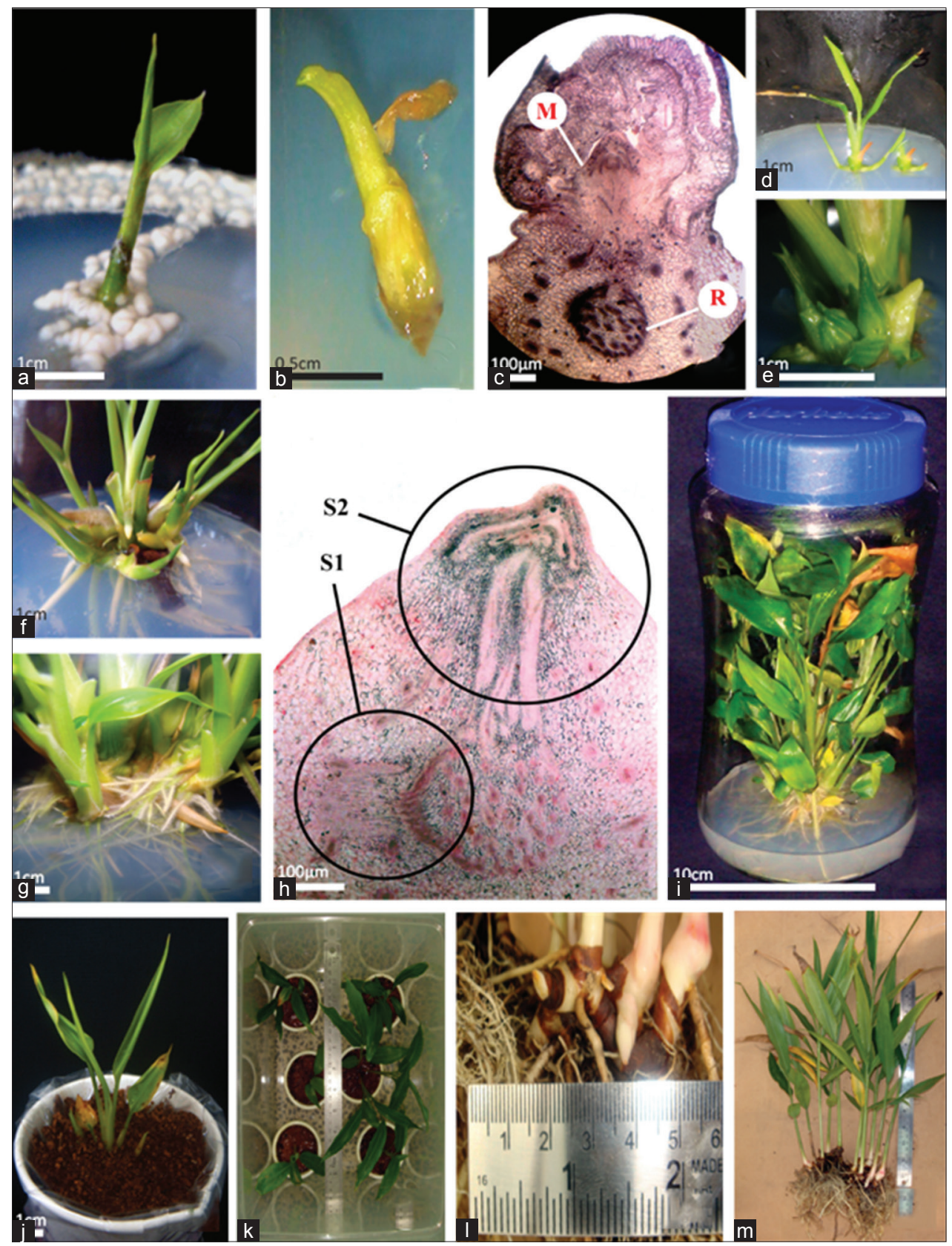

Fig. 3 Micropropagation of Alpinia galanga. (a) Infected rhizome bud explant, (b) sterilized rhizome bud explant on Murashige and Skoog medium, (c) longitudinal section of rhizome bud (stained in Safranin) showing Rhizome (R) and meristem (M), (d) multiple shoots on Murashige and Skoog (MS) medium with BA $13.32 \mu \mathrm{M}$, (e) multiple shoots on MS with thidiazuron (TDZ) $00.45 \mu \mathrm{M}$, (f) multiple shoots on MS medium with TDZ 00.45 + BA $13.32 \mu \mathrm{M}$, (g) rooting on MS medium with 1-naphthaleneacetic acid 10.74 $\mu \mathrm{M}$, (h) handmade cross section of regenerating rhizome (stained in Safranin) showing vascular system of stem 1 (S1) and vascular system of newly forming apical meristem (S2), (i) multiple shoots of A. galanga after rooting, (j) initial hardening of separated stems on sand, soil and coco peat (1:1:1[w:w:w]), (k) hardening of plants inside plastic containers to maintain high moisture content, (1) rhizomes of 4 month hardened plant, and (m) 4 month hardened plants

It was inferred that with rising concentration of BA in synergy with $0.45 \mu \mathrm{M}$ of TDZ, the shoot number significantly increased (from 4 to 9). A combination of TDZ and BA showed not only increase in shoot number but also a significant increase in shoot development which is usually hampered by TDZ. All concentrations of TDZ showed lower multiple shoot production than TDZ $0.45 \mu \mathrm{M}$ in combination with BA (Table 1).

It was interesting to observe that multiple shoots formed in BA and other cytokinins other than TDZ had a different anatomy when compared to that formed on TDZ. In cytokinins other than TDZ, the multiple shoots formed were observed to be positioned at $180^{\circ}$ or $360^{\circ}$ (like a bull horn or a two-horned rhino) as in Fig. 3d but the multiple shoots formed on TDZ were positioned at around $90^{\circ}$ (Fig. 3h). This signifies that regeneration formed by TDZ is considerably different from other cytokinins. Thus, justifying BA and TDZ cytokinin synergy producing better results than the individual cytokinin in the current study.

The present study is the first to discuss a BA and TDZ cytokinin synergy in the micropropagation of a Zingiberaceae member although BA and TDZ combination has been perceived in micropropagation of Psoralea corylifolia a Fabaceae member [33] 
Table 1: Effect of cytokinins on multiple shoot formation in A. galanga, after 8 weeks

\begin{tabular}{|c|c|c|c|c|c|c|}
\hline \multicolumn{4}{|c|}{$\operatorname{PGR}(\mu \mathrm{M})$} & \multirow[t]{2}{*}{ Mean shoots/explant ( \pm SD) } & \multirow[t]{2}{*}{ Mean roots/shoot $( \pm S D)$} & \multirow[t]{2}{*}{ Mean leaves/shoot $( \pm S D)$} \\
\hline BA & KN & TDZ & ZEA & & & \\
\hline 0 & 0 & 0 & 0 & $1.0 \pm 0.0^{\mathrm{j}}$ & $1.2 \pm 0.4^{\mathrm{e}}$ & $1.4 \pm 0.5^{\mathrm{bcd}}$ \\
\hline 08.87 & 0 & 0 & 0 & $3.4 \pm 1.3^{\mathrm{ef}}$ & $3.2 \pm 0.4^{\mathrm{cd}}$ & $1.5 \pm 0.4^{\mathrm{bcd}}$ \\
\hline 13.32 & 0 & 0 & 0 & $4.6 \pm 0.9^{\mathrm{cd}}$ & $3.6 \pm 0.5^{c}$ & $1.4 \pm 0.3^{\mathrm{bcd}}$ \\
\hline 0 & 04.65 & 0 & 0 & $1.4 \pm 0.5^{\mathrm{ij}}$ & $5.8 \pm 0.8^{\mathrm{a}}$ & $1.8 \pm 0.3^{\mathrm{bc}}$ \\
\hline 0 & 09.29 & 0 & 0 & $2.2 \pm 0.4^{\text {ghi }}$ & $6.0 \pm 1.2^{\mathrm{a}}$ & $1.9 \pm 0.6^{\mathrm{bc}}$ \\
\hline 0 & 13.94 & 0 & 0 & $3.2 \pm 0.4^{\mathrm{fg}}$ & $6.4 \pm 1.3^{\mathrm{a}}$ & $1.9 \pm 0.5^{\mathrm{bc}}$ \\
\hline 0 & 0 & 00.22 & 0 & $2.4 \pm 0.5^{\text {fghi }}$ & $2.2 \pm 0.4^{\mathrm{e}}$ & $1.2 \pm 0.2^{\mathrm{cd}}$ \\
\hline 0 & 0 & 00.45 & 0 & $4.2 \pm 0.8^{\mathrm{de}}$ & $2.0 \pm 0.0^{\mathrm{e}}$ & $0.9 \pm 0.2^{\mathrm{d}}$ \\
\hline 0 & 0 & 02.25 & 0 & $1.0 \pm 0.0^{\mathrm{j}}$ & $1.6 \pm 0.5^{\mathrm{de}}$ & $1.4 \pm 0.5^{\mathrm{bcd}}$ \\
\hline 0 & 0 & 0 & 04.56 & $1.0 \pm 0.0^{\mathrm{j}}$ & $5.8 \pm 1.1^{\mathrm{a}}$ & $2.6 \pm 0.5^{\mathrm{ab}}$ \\
\hline 0 & 0 & 0 & 09.12 & $1.8 \pm 0.4^{\mathrm{hij}}$ & $5.4 \pm 0.5^{\mathrm{a}}$ & $2.0 \pm 1.1^{\mathrm{ab}}$ \\
\hline 0 & 0 & 0 & 13.68 & $2.0 \pm 0.0^{\text {hij }}$ & $4.2 \pm 1.1^{\mathrm{bc}}$ & $2.0 \pm 0.5^{\mathrm{a}}$ \\
\hline 04.44 & 0 & 0.45 & 0 & $5.2 \pm 1.1^{\mathrm{c}}$ & $6.4 \pm 1.5^{\mathrm{a}}$ & $1.5 \pm 0.2^{\mathrm{bcd}}$ \\
\hline 13.32 & 0 & 0.45 & 0 & $9.4 \pm 1.3^{\mathrm{a}}$ & $5.6 \pm 0.5^{\mathrm{a}}$ & $1.4 \pm 0.2^{\mathrm{bcd}}$ \\
\hline
\end{tabular}

Within each experiment, mean in a column followed by the same lowercase letter are not significantly different ( $<<0.05)$, SD: Standard deviation

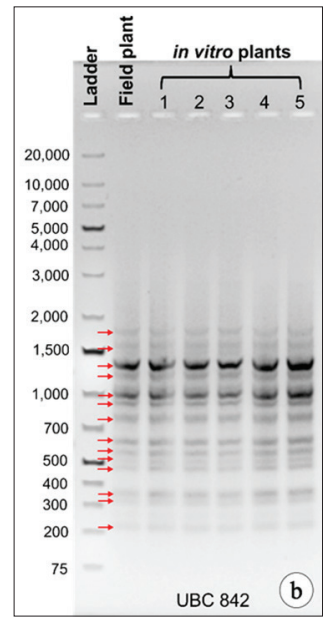

Fig. 4 Agarose gel showing inter simple sequence repeat markers (arrows) of field plant and in vitro plants generated from primer University of British Columbia 842

\section{Rooting and hardening}

Although all cytokinins simultaneously induced rooting which was consistent with previous studies of Zingiberaceae members [31,34], it was still miniscule when compared to the potential of auxins especially NAA (Table 2). The greater number of roots were ideal since shoots with more number of roots survived well during the hardening process.

\section{Genetic fidelity testing}

In vitro regenerated plants have an ambiguity; a considerable degree of somatic mutation can occur in them [35]. ISSR primers have long been effectively used in assessing the genetic integrity of plants and have broadly been used in Zingiberaceae [36]. ISSR markers are preferred against SSR markers in the detection of variations among micropropagated plants since an SSR marker aims at fast evolving hypervariable sequences. ISSR method is similar to the random amplification of polymorphic DNA method, as both are PCR-based methods using appropriate primers, except that ISSR primers are designed from microsatellite regions. They amplify sequences flanking SSR, and the amplifications are of anonymous SSR loci. ISSR loci are predominantly dominant and rarely co-dominant as the size of prevailing space between microsatellites differ. They are most costeffective, fast, and easy to use markers.
Table 2: Effect of auxins on root formation in A. galanga, after 8 weeks

\begin{tabular}{llll}
\hline PGR $(\boldsymbol{\mu M})$ & & & $\begin{array}{l}\text { Average number of } \\
\text { roots/shoot } \mathbf{(} \mathbf{S D})\end{array}$ \\
\hline IAA & IBA & NAA & $4.4 \pm 1.5^{\mathrm{d}}$ \\
\hline 05.71 & 0 & 0 & $4.6 \pm 1.3^{\mathrm{d}}$ \\
11.42 & 0 & 0 & $4.8 \pm 1.6^{\mathrm{d}}$ \\
17.13 & 0 & 0 & \\
& & & $4.0 \pm 0.0^{\mathrm{d}}$ \\
0 & 04.90 & 0 & $5.0 \pm 0.0^{\mathrm{d}}$ \\
0 & 09.80 & 0 & $4.0 \pm 0.0^{\mathrm{d}}$ \\
0 & 14.70 & 0 & $16.2 \pm 2.0^{\mathrm{b}}$ \\
0 & 0 & 05.37 & $20.0 \pm 1.2^{\mathrm{a}}$ \\
0 & 0 & 10.74 & $8.4 \pm 1.3^{\mathrm{c}}$ \\
0 & 0 & 16.11 & $\mathrm{n}^{\mathrm{a}}$ \\
\hline
\end{tabular}

Within each experiment, mean in a column followed by the same lowercase letter are not significantly different $(\mathrm{p}<0.05), \mathrm{SD}$ : Standard deviation, IAA: Indole-3-acetic acid, IBA: Indole-3-butyric acid, NAA: 1-naphthaleneacetic acid, A. galanga: Alpinia galanga

In the current study, UBC ISSR markers were used for the first time in genetic fidelity testing of $A$. galanga. The UBC ISSR markers are the most widely accepted and consistent in comparison to other ISSR markers. The results from the current study concurred with other ISSR works done in the species although utilization of a much more standard group of marker such as UBC adds weightage in the present scenario [3,37].

\section{CONCLUSION}

This is the first report on curbing actinomycetes endophytes in plant tissue culture of $A$. galanga using antibiotic pre-treatments. A pretreatment of rifampicin $100 \mathrm{mg} / \mathrm{l}$ and Fusidic acid $100 \mathrm{mg} / \mathrm{l}$ for $2 \mathrm{hrs}$ gave $70 \%$ sterile explants against actinomycetes; the combination was successful in defending against a broad array of endophytic actinobacteria from soil source. The initial surface sterilization of $0.1 \%$ $(\mathrm{w} / \mathrm{v})$ mercury chloride followed by $0.1 \%(\mathrm{w} / \mathrm{v})$ carbendazim, one after the other for 5 minutes each, gave a sterility of $83.3 \%$ with an acceptable necrosis of $16.7 \%$.

This is also the first report conferring the dissimilar regeneration capabilities of TDZ in comparison to other cytokinins in Zingiberaceae. Thus, a synergy of cytokinins TDZ $0.45 \mu \mathrm{M}$ with BA $13.32 \mu \mathrm{M}$ resulted in the best multiple shoot production of 9.4 shoots per explant. This protocol is apt for producing microbe-free explants from a rhizome or similar underground stems where actinomycete endophytes are present. 


\section{ACKNOWLEDGMENT}

The authors are thankful to Dr. P. A. Jose, Scientist-E1, Department of Forest Botany, Kerala Forest Research Institute, Peechi, Kerala, India for providing the plant material and they also acknowledge the Botanical Survey of India, Southern Circle, Coimbatore, Tamil Nadu, India for extending their plant identification service. The authors also thank the Central Instrumentation Facility under the Centre of Excellence in Life Sciences, Bharathidasan University, Tiruchirappalli, Tamil Nadu, India, for extending their facility for the Genetic fidelity testing. Corresponding author acknowledges University Grants Commission, New Delhi, for Emeritus Fellowship.

\section{REFERENCES}

1. Litz RE, Gray DJ. Organogenesis and somatic embryogenesis. In: Hammerschlag FA, Litz RE, editors. Biotechnology of Perennial Fruit Crops. Wallingford, UK: CABI International; 1992. p. 3-34.

2. Borthakur M, Hazarika J, Singh RS. A protocol for micropropagation of Alpinia galanga. Plant Cell Tissue Organ Cult 1998;55(3):231-3.

3. Parida R, Mohanty S, Nayak S. Evaluation of genetic fidelity of in vitro propagated greater galangal (Alpinia galanga L.) using DNA based markers. Int J Plant Anim Environ Sci 2011;1(3):123-33.

4. Rao K, Chodisetti B, Gandi S, Mangamoori LN, Giri A. Direct and indirect organogenesis of Alpinia galanga and the phytochemical analysis. Appl Biochem Biotechnol 2011;165(5-6):1366-78.

5. Singh NM, Chanu LA, Devi YP. Micropropagation-an in vitro technique for the conservation of Alpinia galanga. Adv Appl Sci Res 2014;5(3):259-63.

6. Taechowisan T, Chuaychot N, Chanaphat S, Wanbanjob A, Shen Y. Biological activity of chemical constituents isolated from Streptomyces sp. Tc052, an endophyte in Alpinia galanga. Int J Pharmacol 2008;4(2):95-101.

7. Taechowisan T, Lumyong S. Activity of endophytic actinomycetes from roots of Zingiber officinale and Alpinia galanga against phytopathogenic fungi. Ann Microbiol 2003;53(3):291-8.

8. Taechowisan T, Wanbanjob A, Tuntiwachwuttikul P, Taylor WC. Identification of Streptomyces sp. Tc022, an endophyte in Alpinia galanga, and the isolation of actinomycin D. Ann Microbiol 2006;56(2):113-7.

9. El-Tarabily KA, Nassar AH, Hardy GE, Sivasithamparam K. Plant growth promotion and biological control of Pythium aphanidermatum a pathogen of cucumber, by endophytic actinomycetes. Eur J Plant Pathol 2009;128(4):527-39.

10. Nimnoi P, Pongsilp N, Lumyong S. Endophytic actinomycetes isolated from Aquilaria crassna Pierre ex Lec and screening of plant growth promoters production. World J Microbiol Biotechnol 2010;26(2):193-203.

11. Ramesh KV, Garima M, Pradeep S, Jha KK, Khosa RL. Alpinia galanga - An important medicinal plant: A review. Pharma Sin 2011;2(1):142-54.

12. Ravichandra V, Hanumantharayappa B, Papasani VM. Evaluation of cardio protective activity of galangin against doxorubicin induced cardiomyopathy. Int J Pharm Pharm Sci 2014;6(9):86-90.

13. Barik BR, Kundu AB, Dey AK. Two phenolic constituents from Alpinia galanga rhizomes. Phytochemistry 1987;26(7):2126-7.

14. Das A, Santhy KS. Chemical characterisation of Alpinia galanga (L.) Willd by GC-MS, XRD, FTIR and UV-Vis spectroscopic methods. Int J Pharm Pharm Sci 2015;7(9):499-501.

15. Daubresse N, Francesch C, Mhamdi F, Rolando C. A mild synthesis of coumaryl, coniferyl, sinapyl aldehydes and alcohols. Synthesis 1994;4:369-71.

16. Lee SJ, Ando T. Optically active 1'-acetoxychavicol acetate and its positional isomers: Synthesis and repellent effect against adzuki bean weevil. J Pestic Sci 2001;26(1):76-81.

17. Loubinoux B, Miazimbakana J, Gerardin P. Reactivity of new precursors of quinone methides. Tetrahedron Lett 1989;30(15):1939-42.

18. Noro T, Sekiya T, Katoh M, Oda Y, Miyase T, Kuroyanagi M, Ueno A, Fukushima S. Inhibitors of xanthine oxidase from Alpinia galanga. Chem Pharm Bull 1988;36(1):244-8.

19. Goel MK, Kukreja AK, Bisht NS. In vitro manipulations in St. John's wort (Hypericum perforatum L.) for incessant and scale up micropropagation using adventitious roots in liquid medium and assessment of clonal fidelity using RAPD analysis. Plant Cell Tissue Organ Cult 2009;96:1-9.

20. Jain SM. Tissue culture-derived variation in crop improvement. Euphytica 2001;118(2):153-66.

21. Amalraj VA, Velayudhan KC, Abraham Z. Threatened medicinal plants in western ghats. In: Karunakaran CK, editor. Proceedings Symposium on Rare Endangered Endemic Plants Western Ghats. Thiruvananthapuram, Kerala, India: Kerala Forest Department; 1991. p. $215-20$.

22. Phillips R, Arnott SM, Kaplan SE. Antibiotics in plant tissue culture: Rifampicin effectively controls bacterial contaminants without affecting the growth of short-term explant cultures of Helianthus tuberosus. Plant Sci Lett 1981;21(3):235-40.

23. Murashige T, Skoog F. A revised medium for rapid growth and bioassays with tobacco tissue cultures. Physiol Plant 1962;15(3):473-97.

24. Porebski S, Bailey LG, Baum BR. Modification of CTAB DNA extraction protocols for plants containing high polysaccharide and polyphenol components. Plant Mol Biol Rep 1997;15(1):8-15.

25. Abdelmageed AH, Faridah QZ, Norhana FM, Julia AA, Kadir MA. Micropropagation of Etlingera elatior (Zingiberaceae) by using axillary bud explants. J Med Plants Res 2011;5(18):4465-9.

26. Rakkimuthu R, Jacob J, Aravinthan K. In vitro micropropagation of Alpinia zerumbet variegate, an important medicinal plant, through rhizome bud explants. Res Biotechnol 2011;2(1):7-10.

27. Wilkins WL. Disinfection, Sterilization, and Preservation. $5^{\text {th }}$ ed. Philadelphia, PA: Lea \& Febiger; 2000

28. Kiso T, Fujita K, Ping X, Tanaka T, Taniguchi M. Screening for microtubule-disrupting antifungal agents by using a mitotic-arrest mutant of Aspergillus nidulans and novel action of phenylalanine derivatives accompanying tubulin loss. Antimicrob Agents Chemother 2004;48(5): 1739-48.

29. Campbell EA, Korzheva N, Mustaev A, Murakami K, Nair S, Goldfarb A, et al. Structural mechanism for rifampicin inhibition of bacterial rna polymerase. Cell 2001;104(6):901-12.

30. Nasher MA, Hay RJ. Synergy of antibiotics against Streptomyces somaliensis isolates in vitro. J Antimicrob Chemother 1998;41(2):281-4.

31. Kochuthressia KP, Britto SJ, Raj LJ, Jaseentha MO, Senthilkumar SR. Efficient regeneration of Alpinia purpurata (Vieill.) K. Schum. Plantlets from rhizome bud explants. Int Res J Plant Sci 2010;1(2):43-7.

32. Tefera W, Wannakrairoj S. A micropropagation method for korarima (Aframomum corrorima [Braun] Jansen). ScienceAsia 2004;30:1-7.

33. Baskaran P, Jayabalan N. Effect of growth regulators on rapid micropropagation and psoralen production in Psoralea corylifolia L. Acta Physiol Plant 2008;30:345-51.

34. Yusuf NA, Annuar MM, Khalid N. Rapid micropropagation of Boesenbergia rotunda (L.) Mansf. Kulturpfl. (A valuable medicinal plant) from shoot bud explants. Afr J Biotechnol 2011;10(7):1194-9.

35. Rani V, Raina SN. Genetic fidelity of organized meristem-derived micropropagated plants: A critical reappraisal. In Vitro Cell Dev Biol Plant 2000;36(5):319-30.

36. Mohanty S, Parida R, Sahoo S, Nayak S. In vitro conservation of nine medicinally and economically important species of zingiberaceae from Eastern India. Proc Natl Acad Sci India Sect B Biol Sci 2014;84(3):799-803.

37. Rajasekharan PE, Abdul-Kareem VK, Ravish BS, Mini S. Analysis of genetic diversity in Alpinia galanga using ISSR markers. Indian J Plant Genet Resour 2016;29(2):194-8. 